\title{
Allelopathic Potentiality of Heliotropium curassavicum L. and H.bacciferum Forssk.
}

\author{
H.F. Farrag ${ }^{1 \& 2 *}$, A. M. Sliai ${ }^{2}$ and T.F. Mhmas ${ }^{2}$ \\ ${ }^{1}$ Botany Department, Faculty of Science, Cairo University \\ Egypt and ${ }^{2}$ Biology Department, Faculty of Science, Taif \\ University, Saudi Arabia.
}

\begin{abstract}
POT EXPERIMENT was conducted under natural conditions in $A$ an open greenhouse to study the allelopathic potentiality of Heliotropium curassavicum and $H$. bacciferum on the growth parameters of Calotropis procera and Faba sativa. Ground shoot powder with three application rates of $2.5,5$ and $10 \mathrm{~g}$ per $8 \mathrm{~kg}$ soil for the two Heliotropium species treatment referred as $\mathrm{T}_{1}, \mathrm{~T}_{2}$ and $\mathrm{T}_{3}$; respectively, were evenly mulched on the soil surface of the test species. The present study showed that the inhibitory effect of H.curassavicum on the growth of the test species was generally more than that of $H$. bacciferum. Values of root-shoot (R:S) ratios for C.procera treated with either $H$. curassavicum or $H$. bacciferum mulches, were less than unity while the same measurements for $F$.sativa were more than unity. Less number of flowers per individual was recorded in the treated $F$. sativa in comparison to that of C.procera. Comparing dry matter allocation of $C$. procera plant organs in most growth stages and treatments demonstrated that, percent allocation of leaves $>$ stem $>$ root $>$ flowers. Dry matter allocation to roots in the case of $F$. sativa plants treated with either H.curassavicum or $H$. bacciferum, gave maximum values as compared to other plant organs. Growth analysis of the two test species and the variation in growth criteria in response to the effect of mulching treatments included relative growth rate (RGR), net assimilation rate (NAR), leaf area ratio (LAR), specific leaf area (SLA) and specific leaf weight (SLW) were studied. The RGRs of the two test species generally decreased as the plant age proceeded. The present study recommends the use of the two Heliotropium species for the biocontrol of harmful shrubs such as $C$. procera and at the same time alerts of the inhibitory effect of these species on the growth of economic plants such as $F$. sativa.
\end{abstract}

Keywords: Allelopathic potentiality, Heliotropium curassavicum, Heliotropium bacciferum, Dry matter allocation, Growth parameters.

Allelopathy involves any direct or indirect harmful effect of one plant through release of chemical compounds on the other. These allelopathic chemicals inhibit seed germination or reduce growth of the other plant species. Moreover,

Corresponding author, E-mail: hfarrag2012@hotmail.com;

Tel: +966550791544 
allelochemicals affect cell division, production of plant hormones, membrane permeability, germination of pollen grains, mineral uptake, movement of stomata, pigment synthesis, photosynthesis, respiration, protein synthesis, nitrogen fixation, specific enzyme activities and development of conductive tissue (Rice, 1984; Djurdjević et al. 2012; Mansour, 2013). Allelochemicals include phenolic acids, coumarins, terpenoids and flavonoides. These compounds are released from the plants as vapour, as leachings from the foliage, as exudates from the roots, or in the course of breakdown or decomposition of dead plant residues. Allelopathy is existent in the natural and agricultural ecosystems. It is a mechanism by which weeds affect crop growth and yield. Allelopathy is possibly a significant factor in maintaining the present balance among the various plant species (Kim and Lee 2011). There is increasing evidence that many plant invaders interfere with native plants through allelopathy. This allelopathic interference may be a key mechanism of plant invasiveness (Inderjit et al., 2008). Several studies demonstrated the negative relationship between native and exotic species (Thorpe et al., 2009). There is much evidence that allelochemicals from weeds inhibit crop growth (Florentine et al. 2005). Farrag (2007) studied the allelopathic effects of three weeds; namely, Heliotropium curassavicum, Bassia indica and Chenopodium ambrosioides on the associated weeds and crops in the Nile Delta region, Egypt.

In Saudi Arabia, Heliotropium curassavicum L. and Heliotropium bacciferum (Boraginaceae) have become two of the most common polycarpic weeds infesting many Wadis and newly reclaimed fields at many areas of Taif regions (Farrag 2012). Because of their vigorous growth and natural ability to colonize the disturbed salt affected sand flats, the species spreads rapidly invading the newly reclaimed lands and the surrounding fields as a troublesome weed (Hegazy, 1994). The success of different Heliotropium species as weeds can be attributed to the production of adventitious root buds which allow for the plant's perennation and spread (Hegazy, 1994).

The aim of the current work is to compare the allelopathic potentiality of two invasive Heliotropium species (Boraginaceae); namely, Heliotropium curassavicum L. and Heliotropium bacciferum Forssk., on the growth of one important economic crop; Faba sativa (Fabaceae) and one common toxic shrub; Calotropis procera (Asclepiadaceae) in Taif.

\section{Material and Methods}

\section{Materials}

The seeds of the crop; F.sativa were obtained commercially from the store in Taif, while seeds of $C$. procera were collected from the plants of naturally growing populations at Wadi Al-Argy, Seesed, about $5 \mathrm{~km}$ east of Taif $\left(21^{0} 17^{\prime}\right.$ $\mathrm{N}$ and $40^{\circ} 29^{\prime} \mathrm{E}$ and altitude of $\left.1595 \mathrm{~m}\right)$. Plastic pots $(18 \mathrm{~cm}$ diameter and $25 \mathrm{~cm}$ depth) were used. The soil was obtained from the field study site. The soil samples were air-dried and passed through 2-mm sieve to separate litter and gravel. The air-dried sieved soil was filled into the experimental pots

Egypt. J. Bot., 54, No. 2 (2014) 
(8 kg soil/pot). H.curassavicum and H.bacciferum plant materials for the purpose of mulching experiment were collected from naturally growing plants at Wadi Al-Argy, Seesed- Taif. The collected plant samples washed with distilled water then separated into shoots and roots air dried and finally grind the shoots to test the mulching purposes.

\section{Experimental design}

The experiment was conducted in an open greenhouse at Wadi Argy, under the external natural environmental conditions in Seesed area. The prevailing climatic conditions during the experimental period includes temperature which ranged between a minimum of $12.8^{\circ} \mathrm{C}$ in November to a maximum value of $34.4^{\circ} \mathrm{C}$ in July. Relative humidity ranged between minimum of $23 \%$ in June to a maximum value of $55 \%$ in November (Farrag, 2012). Ten seeds were sown in every pot at depth of $1 \mathrm{~cm}$. Ground shoot powder with three application rates of 2.5, 5 and $10 \mathrm{~g}$ per $8 \mathrm{~kg}$ soil for each Heliotropium species treatment referred as $\mathrm{T}_{1}, \mathrm{~T}_{2}$ and $\mathrm{T}_{3}$; respectively, were evenly mulched on the soil surface of the corresponding pot. In control treatment the seeds were sown in soils without mulching. Total of twelve pots were used for each treatment, three of which were harvested for each of the four growth stages; seedling, juvenile, mature and flowering. Seedling emergence was monitored daily. After the seedling emergence ceased, seedlings were thinned to the most similar healthy five individuals per pot. The pots were watered regularly and equally at the same time for all treatments when needed. The amount of water per pot was adjusted to avoid leaching of the soil water out of pots.

\section{Harvest and measurements}

Plant materials were harvested and data gathered at the four growth stages; seedling, juvenile, mature and flowering stages for all target plants. At each harvest stage, whole pot of each treatment was gently inverted and whole plants harvested individually by carefully clearing the soil with pressurized tap water. The growth criteria measurements included root depth, shoot height, leaf area, number of leaves and flowers. The whole plant then divided into separate organs; roots, stems, leaves, and reproductive organs (flowers), which then oven dried at $75^{\circ} \mathrm{C}$ until constant weight. Dry phytomass was recorded for each plant organ. Five replicates were used for every measurement.

Root/shoot ratios, percent dry matter allocation and growth parameters including Relative Growth Rate (RGR), Net Assimilation Rate (NAR), Leaf Area Ratio (LAR), Specific Leaf Area (SLA) and Specific Leaf Weight (SLW) were calculated according to Hunt (1978) by using the following equations: The RGR was calculated as gm $\mathrm{gm}^{-1} \mathrm{day}^{-1}$ over the time interval as: $\mathrm{RGR}=\left(\ln \mathrm{W}_{2}-\ln \mathrm{W}_{1}\right) /\left(\mathrm{t}_{2}-\mathrm{t}_{1}\right)$ Where, $\mathrm{W}_{1}$ and $\mathrm{W}_{2}$ are weights at time $t_{1}$ and $t_{2}$, respectively. The NAR was calculated as $\mathrm{gm} \mathrm{mm}^{-2}$ day $^{-1}$ over the time interval as: $\mathrm{NAR}=\left\{\left(\ln \mathrm{A}_{2}-\ln \mathrm{A}_{1}\right) /\left(\mathrm{A}_{2}-\mathrm{A}_{1}\right)\right\} X\left\{\left(\mathrm{~W}_{2}\right.\right.$ $\left.\left.-\mathrm{W}_{1}\right) /\left(\mathrm{t}_{2}-\mathrm{t}_{1}\right)\right\}$, and LAR calculated as $\mathrm{mm}^{2} \mathrm{gm}^{-1}$ as follow: $\mathrm{LAR}=\left\{\left(\ln \mathrm{W}_{2}-\ln \mathrm{W}_{1}\right)\right.$ $\left./\left(\ln \mathrm{A}_{2}-\ln \mathrm{A}_{1}\right)\right\} X\left\{\left(\mathrm{~A}_{2}-\mathrm{A}_{1}\right) /\left(\mathrm{W}_{2}-\mathrm{W}_{1}\right)\right\}$ where, $\mathrm{W}_{1}, \mathrm{~W}_{2}$ are weights and $\mathrm{A}_{1}, \mathrm{~A}_{2}$ are leaf areas at time $t_{1}$ and $t_{2}$, respectively. The SLA was calculated as $\mathrm{mm}^{2} \mathrm{gm}^{-1}$ as: SLA = Leaf area / Leaf weight. The SLW was calculated as $\mathrm{mg} \mathrm{mm}^{-2}$ as: SLW = Leaf weight / Leaf area 


\section{Statistical analysis}

Data were analyzed by ANOVA test to determine the significance of differences among the mean values at $\mathrm{P}<0.05$ and $\mathrm{P}<0.01$ probability levels using a "general linear model" procedure of the Statistical Analysis System (SAS) program (SAS Institute, 1985). The correlation between RGR and other growth parameters was undertaken by using SPSS program version 10 .

\section{Vegetative attributes}

\section{Results}

The effect of mulching using either $H$. curassavicum or $H$. bacciferum shoot powder on shoot height and root depth of $C$. procera and $F$. sativa demonstrated significant inhibitory effects on both shoot and root lengths in most growth stages (Fig. 1, 2). The inhibitory effect of $H$. curassavicum was generally more than that of $H$. bacciferum as follows

The mean shoot and root lengths of $C$. procera treated with $H$. curassavicum powder showed significant $(p<0.01)$ differences and varied as a function of mulch concentration and growth stages (Fig. 1). Average shoot lengths recorded $4.3,3.9,2.5$ and $2 \mathrm{~cm}$ at the seedling growth stage for the treatments of control, $\mathrm{T}_{1}, \mathrm{~T}_{2}$ and $\mathrm{T}_{3}$; respectively, while these values greatly increased at the late growth stage (flowering) and recorded 84.7, 77.9, 72.4 and $62.4 \mathrm{~cm}$ for shoots of the same type of mulch and treatments. Root depths of $C$. procera followed the same inhibitory effect of mulch. For example, the measured root depths of C.procera were significantly $(p<0.05)$ decreased from $36 \mathrm{~cm}$ into $14.3 \mathrm{~cm}$ for C.procera roots of control and $\mathrm{T}_{3}$; respectively. Almost all H. bacciferum mulch concentrations showed the same inhibitory effect occurred in shoots and roots of C. procera but treated with H. curassavicum mulch (Fig. 1).

Considering the effect of H.curassavicum and H.bacciferum mulches on shoot and root lengths of F.sativa, the illustrated data in (Fig. 2) followed the same inhibitory effect of the mulch treatments on theses lengths through the different growth stages. Considering shoot heights of $F$. sativa treated with $H$. curassavicum at the flowering growth stage, the recorded means were 32.7, 25.7, 20.3 and $17.3 \mathrm{~cm}$ for treatments control, $\mathrm{T}_{1}, \mathrm{~T}_{2}$ and $\mathrm{T}_{3}$; respectively, while the recorded values were $32.7,29.3,23.6$ and $19 \mathrm{~cm}$ for the same treatments and growth stage of $F$. sativa plants treated with $H$. bacciferum (Fig. 2). In addition, the recorded $F$. sativa average root depths and treated with $H$. curassavicum, were 47.3, 43, 22 and $14.6 \mathrm{~cm}(p<0.05)$ at the mature growth stage for the treatments of control, $\mathrm{T}_{1}, \mathrm{~T}_{2}$ and $\mathrm{T}_{3}$; respectively and in these values were relatively higher and recorded 29.6, 24.6, 19.7 and $17.3 \mathrm{~cm}(\mathrm{p}<0.01)$ for roots of $F$. sativa plants treated with $H$. bacciferum at the same growth stage (Data not shown).

Egypt. J. Bot., 54, No. 2 (2014) 

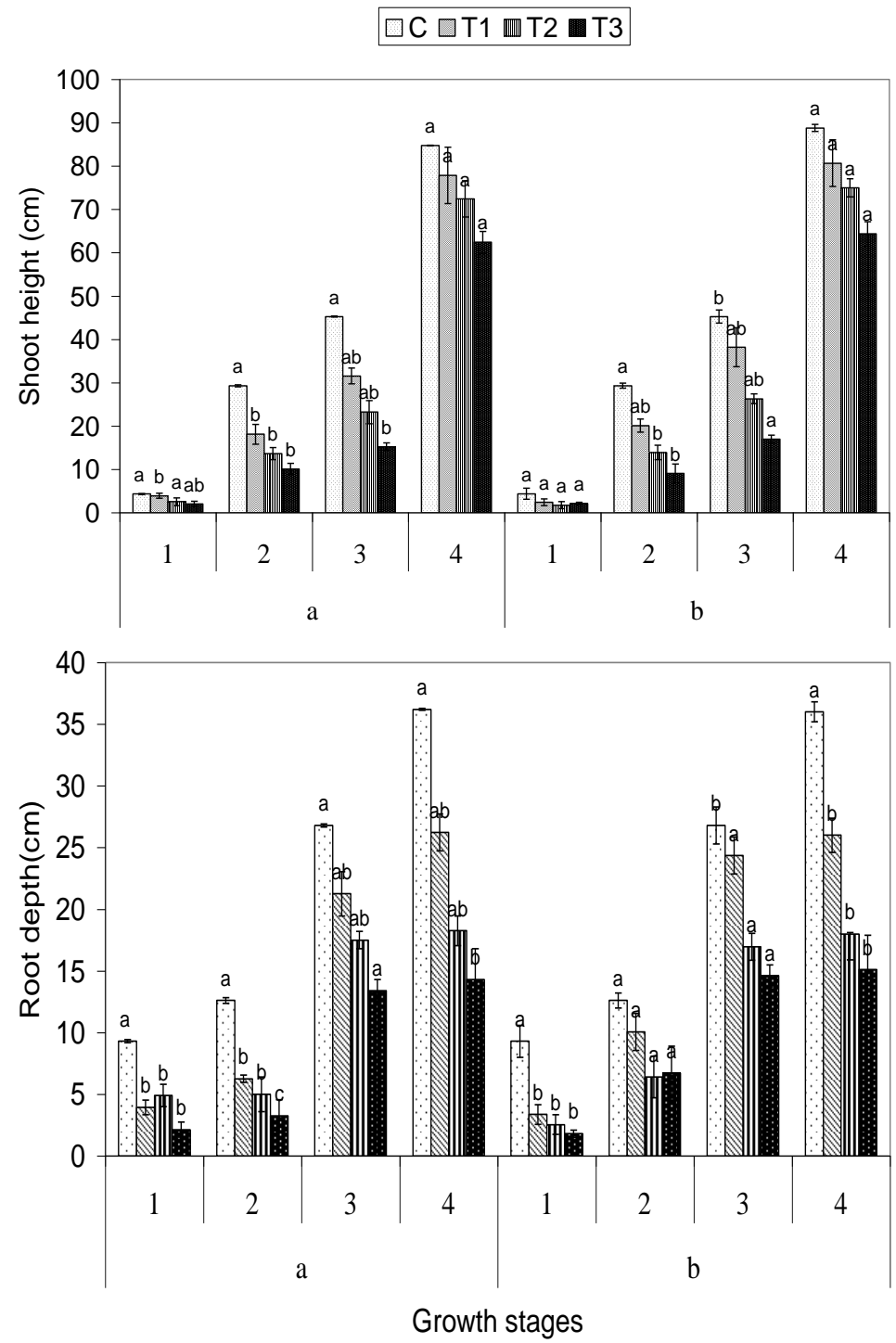

Fig.1. Mean and standard deviation of shoot height and root depth of $C$. procera growing under mulching treatment of $\boldsymbol{H}$. curassavicum (a) and $\boldsymbol{H}$. bacciferum (b) at different growth stages; $1=$ Seedling, 2 = Juvenile, 3 = Mature and 4= Flowering. Vertical bar around the mean is the standard deviation. Values with the same letter were not significantly different according to the Dunnett test. 

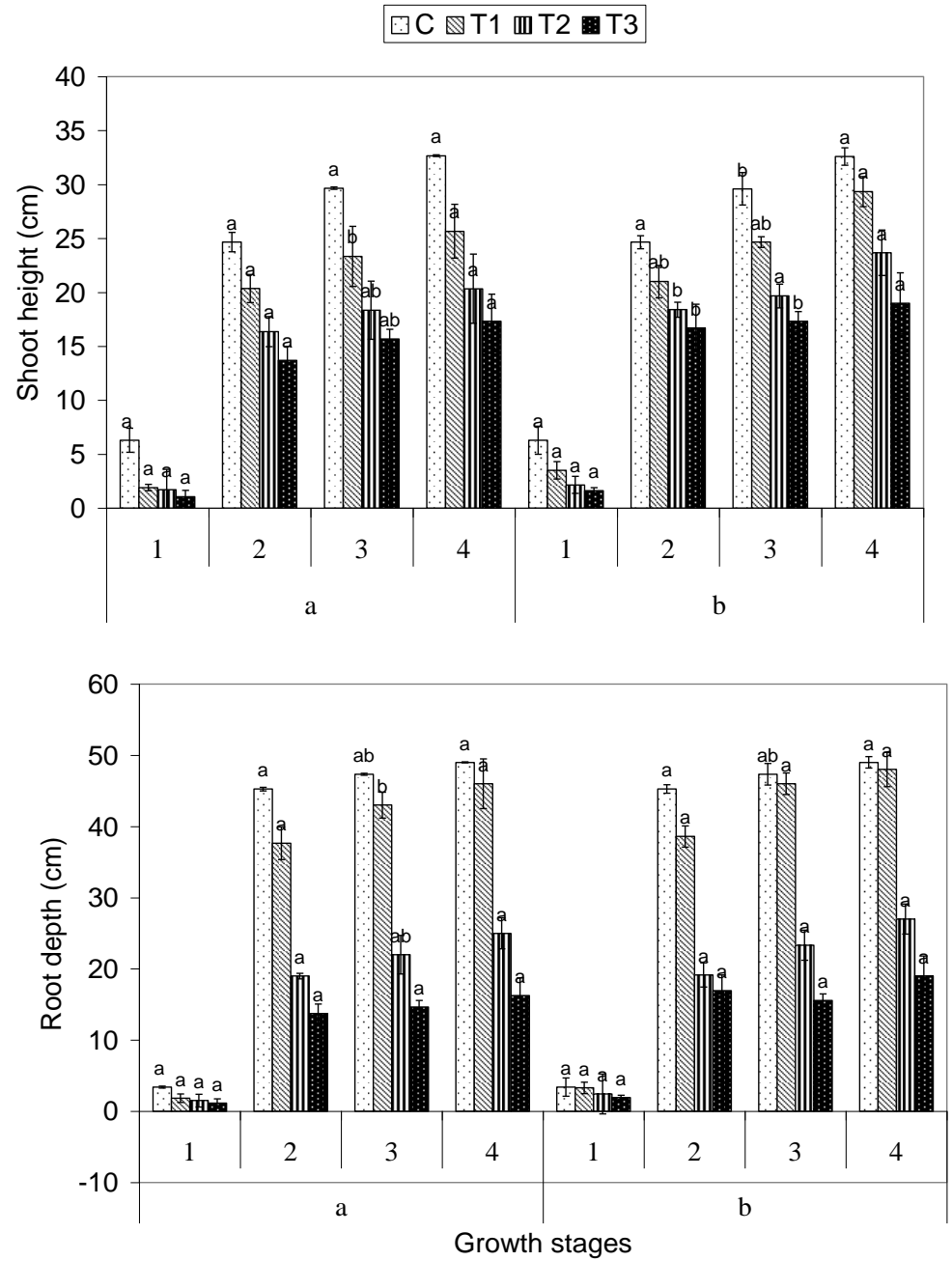

Fig. 2. Mean and standard deviation of shoot height and root depth of $F$. sativa growing under mulching treatment of $\boldsymbol{H}$. curassavicum (a) and $\boldsymbol{H}$. bacciferum (b) at different growth stages; $1=$ seedling, $2=$ juvenile, $3=$ mature and $4=$ flowering. Vertical bar around the mean is the standard deviation.

The illustrated data in Fig. 3, showed that the values of root-shoot (R:S) ratios for $C$. procera treated with either $H$. curassavicum or $H$. bacciferum mulches, were $(<1)$ except for the seedling growth stage, then those for $F$. sativa $(>1)$. Considering $(\mathrm{R}: \mathrm{S})$ ratios that recorded by $C$. procera treated with H.curassavicum for instance, the values ranged between 0.32 and 0.43 in the juvenile growth stage using the different mulch concentrations, while the (R:S) ratios attained by $F$. sativa ranged between 1.01 and 1.83 for the same growth stage and treatments (Fig. 3).

Egypt. J. Bot., 54, No. 2 (2014) 
C. procera

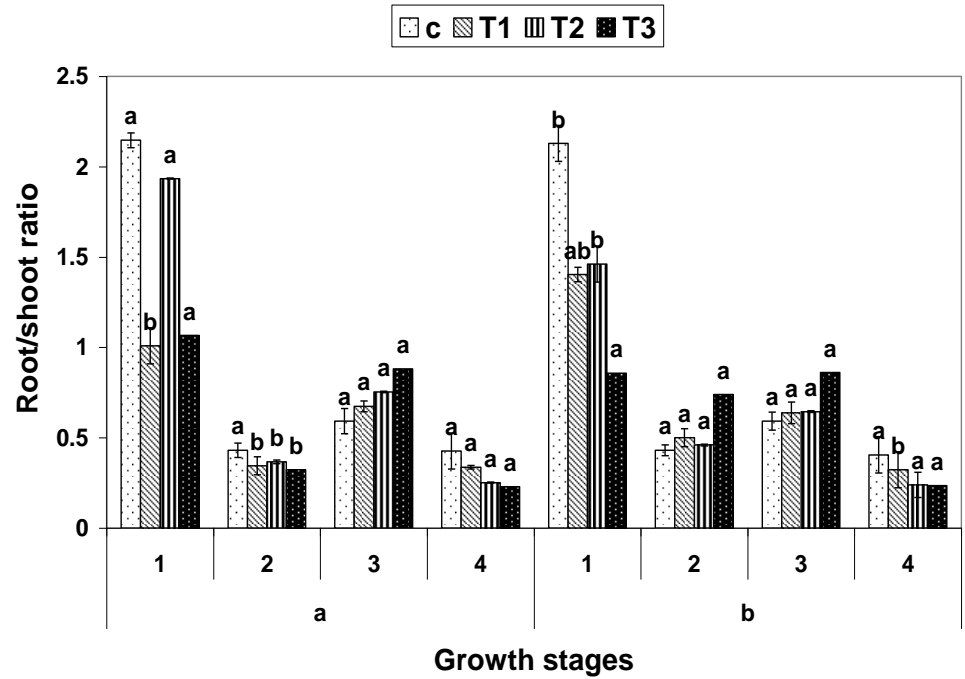

F. sativa

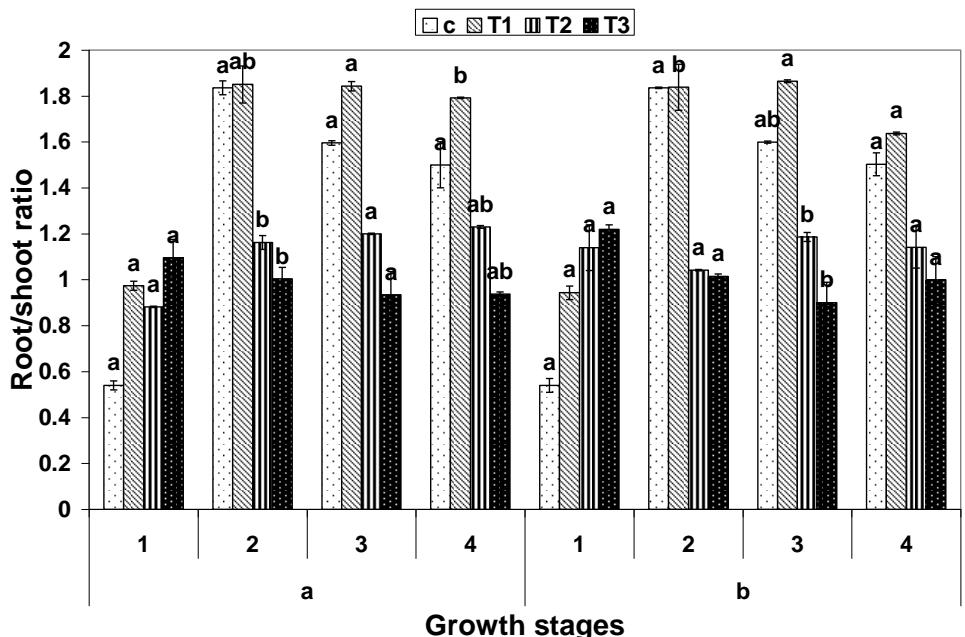

Fig. 3. Mean and standard deviation of root/shoot ratio of $C$. procera and $F$. sativa, growing under mulching treatment of $\boldsymbol{H}$. curassavicum (a) and $\boldsymbol{H}$. bacciferum (b) at different growth stages; $1=$ seedling, $2=$ juvenile, $3=$ mature and $4=$ flowering. Vertical bar around the mean is the standard deviation. 


\section{Reproductive attributes}

Less number of flowers per individual was recorded in F.sativa in comparison to that of $C$. procera. The average number of flowers were 10.33, 9.66, 9.33 and 8.33 for C.procera plants mulched by $H$. curassavicum, while the recorded ones were significantly $(p<0.05)$ reduced to 6.66, 2.33, 1.66 and 1 in the case of $F$. sativa plants. In addition, the inhibitory effect of $H$. curassavicum on the number of flowers of the two studied test species was more than that $H$.bacciferum. The average number of flowers per $F$. sativa individual treated by $H$. bacciferum were $3.54,2.56$ and 1.33 and these values relatively decreased into $2.33,1.66$ and 1 for the same test species but treated with $H$. curassavicum (Table 1).

TABLE 1. Number of flowers of $C$. procera and $F$. sativa subjected to the mulching treatment of $(a)=H$. curassavicum and $(b)=H$. bacciferum in the flowering stage. Mean values are given and values between bracts are the standard deviations. $* \mathbf{P}<0.05$, $* * \mathbf{P}<0.01$, n.s. $=$ non significant.

\begin{tabular}{|c|c|c|c|c|}
\hline \multirow{2}{*}{ Treatment } & \multicolumn{2}{|c|}{ C.procera } & \multicolumn{2}{c|}{ F.sativa } \\
\cline { 2 - 5 } & (a) & (b) & (a) & (b) \\
\hline Control & $10.33 \pm 1.88^{\mathrm{a}}$ & $11.66 \pm 1.24^{\mathrm{a}}$ & $6.66 \pm 1.69^{\mathrm{a}}$ & $7.66 \pm 0.59^{\mathrm{a}}$ \\
\hline $\mathrm{T}_{1}$ & $9.66 \pm 0.94^{\mathrm{a}}$ & $10.33 \pm 0.48^{\mathrm{ab}}$ & $2.33 \pm 0.47^{\mathrm{b}}$ & $3.54 \pm 0.12^{\mathrm{ab}}$ \\
\hline $\mathrm{T}_{2}$ & $9.33 \pm 0.47^{\mathrm{a}}$ & $9.66 \pm 0.48^{\mathrm{ab}}$ & $1.66 \pm 0.47^{\mathrm{b}}$ & $2.56 \pm 0.08^{\mathrm{a}}$ \\
\hline $\mathrm{T}_{3}$ & $\begin{array}{c}8.33 \pm 0.47^{\mathrm{a}} \\
\text { n.s. }\end{array}$ & $\begin{array}{c}8.66 \pm 0.45^{\mathrm{b}} \\
*\end{array}$ & $\begin{array}{c}1.00 \pm 0.01^{\mathrm{b}} \\
{ }^{2}\end{array}$ & $\begin{array}{c}* 33 \pm 0.01^{\mathrm{b}} \\
* *\end{array}$ \\
\hline
\end{tabular}

\section{Dry matter allocation}

The allocation of dry matter to leaves of $C$. procera plants mulch by H.curassavicum was higher than the other plant organs in almost all growth stages except the juvenile stage (Fig. 4, a). The percent of dry matter allocated to leaves reached $49.02 \%$ in C. procera treated plants $\left(\mathrm{T}_{1}\right)$ by $H$. curassavicum during the flowering growth stage, while the recorded dry matter allocations for stem, root and flowers were 34.04, 16.71 and $0.28 \%$; respectively. Maximum allocation to $C$. procera leaves $(71.89 \%)$ was recorded in the seedling stage for control plants, while minimum allocation to the same organ $(9.95 \%)$ was recorded in the $C$. procera plants treated by $\mathrm{T}_{2}$ rate of $H$. bacciferum mulch (Fig. 4,b). In general, comparing dry matter allocation of the different $C$. procera plant organs in most growth stages and treatments demonstrated that, percent allocation of leaves $>$ stem $>$ root $>$ flowers.

In contrast to the above mentioned results, dry matter allocation to roots in the case of $F$. sativa plants treated with either $H$. curassavicum or H. bacciferum, gave maximum values as compared to other plant organs. The recorded dry matter allocation for $F$. sativa plants treated by $H$. bacciferum $\left(\mathrm{T}_{2}\right)$ were 46.39 , 38.14 and $15.46 \%$ in root, leaves and stem; respectively (Fig. 5, a). Moreover,

Egypt. J. Bot., 54, No. 2 (2014) 
maximum allocation which occurred in $F$. sativa root $(49.57 \%)$, was recorded in plants subjected to $\mathrm{T}_{2} H$. bacciferum mulch (Fig. 5,b). Generally, the illustrated data revealed that, the allocation of $F$. sativa dry matter was in the order towards root $>$ leaves $>$ stem $>$ flowers, which did not follow the same pattern mentioned above in the case of $C$. procera.

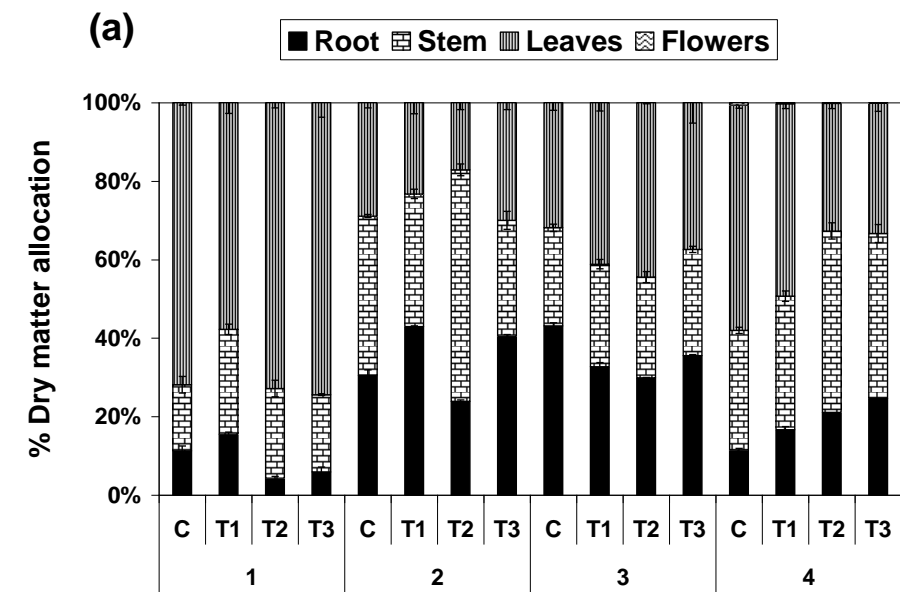

(b)

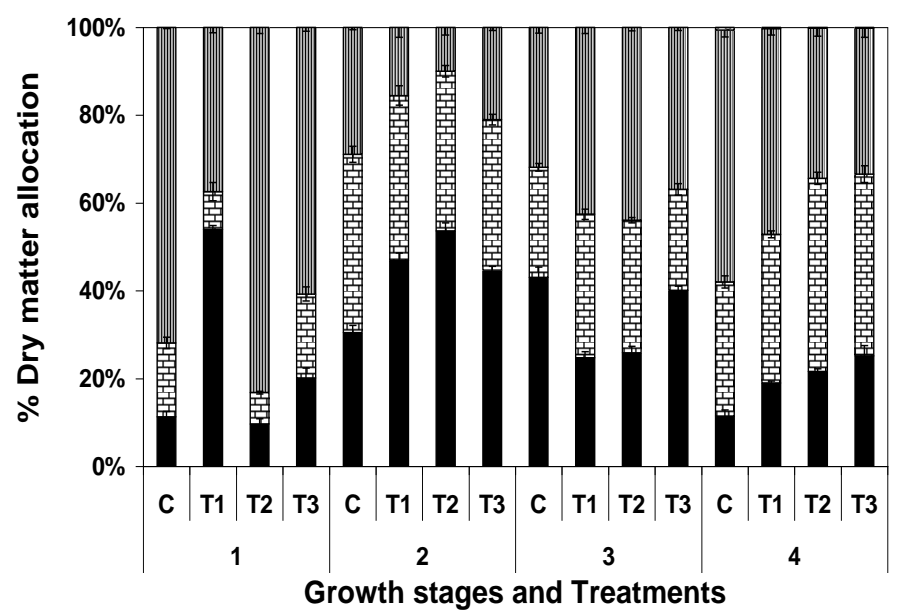

Fig. 4. Dry matter allocation of $C$. procera subjected to the mulching treatment of $H$. curassavicum (a) and $H$. bacciferum (b) at different growth intervals; $1=$ seedling-juvenile, $2=$ juvenile-mature and $3=$ mature-flowering. Vertical bar around the mean is the standard deviation. 


\section{(a) $\quad$ Root 圄Stem 血 Leaves 园 Flowers}

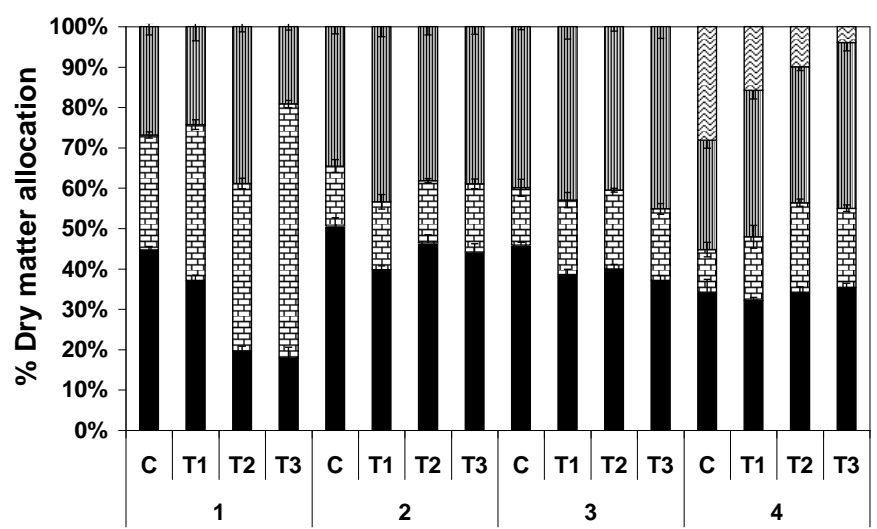

(b)

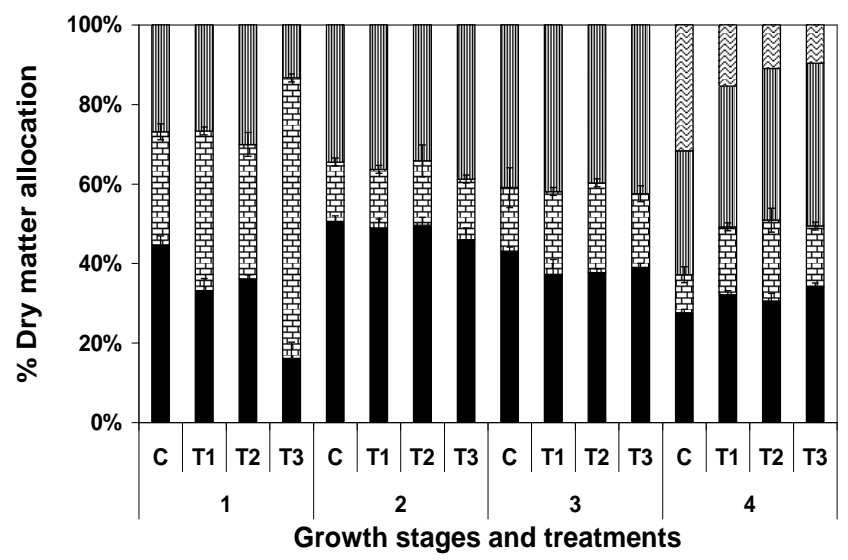

Fig. 5. Dry matter allocation of $F$. sativa subjected to the mulching treatment of H.curassavicum (a) and H. bacciferum (b) at different growth intervals; 1=seedling-juvenile, $2=$ juvenile-mature and $3=$ mature-flowering. Vertical bar around the mean is the standard deviation.

\section{Growth analysis}

Growth analysis of the two test species and the variation in growth parameters in response to the effect of mulching treatments included relative growth rate (RGR), net assimilation rate (NAR), leaf area ratio (LAR), specific leaf area (SLA) and specific leaf weight (SLW) were illustrated in Fig. (6-9). The correlation between RGR and other growth parameters is shown in Table 2. 
C. procera

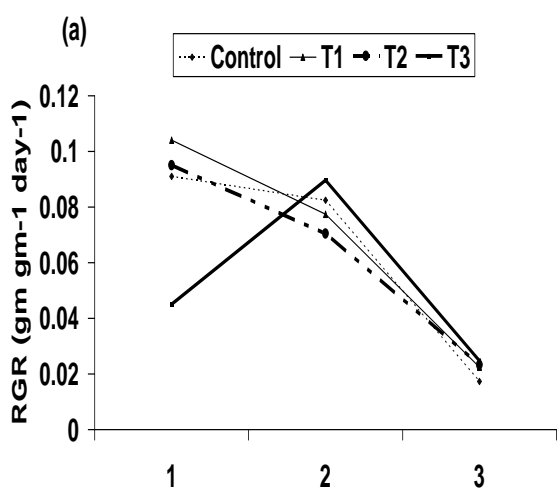

(c)

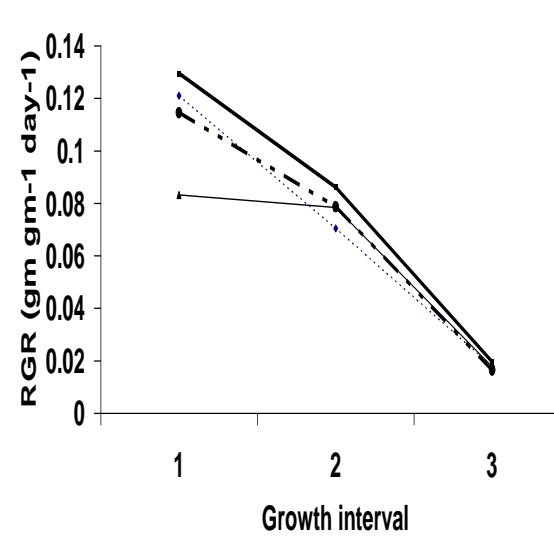

F. sativa
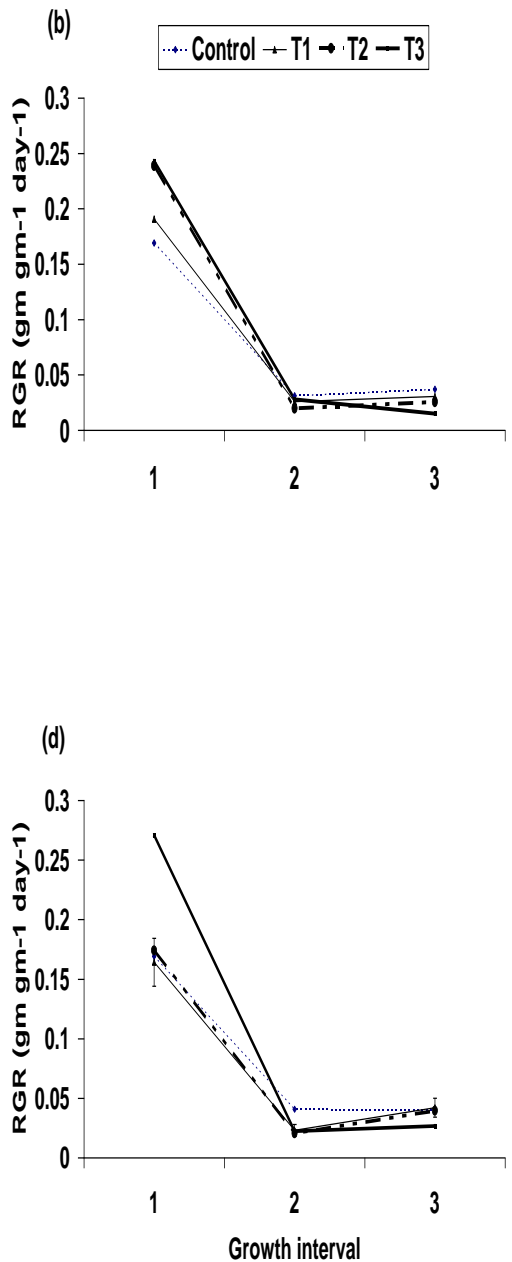

Fig. 6. Relative growth rate (RGR) of $C$. procera (a,c) and $F$. sativa (b,d) subjected to the mulching treatment of $H$. curassavicum $(a, b)$ and H.bacciferum (c,d) at different growth intervals; $1=$ =seedling-juvenile, $2=$ juvenile-mature and $3=$ mature-flowering. Vertical bar around the mean is the standard deviation. 


\section{C. procera}

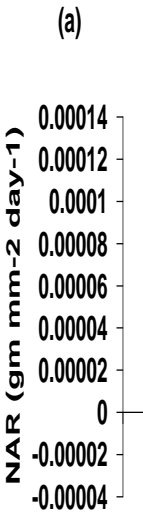

(a)

$$
\text { . Control }-\mathrm{T} 1 \rightarrow \mathrm{T} 2-\mathrm{T} 3
$$

(b) $\quad$ Control $+\mathrm{T} 1 \rightarrow \mathrm{T} 2-\mathrm{T} 3$

$\hat{\tau}^{0.008}$

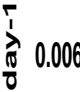

है 0.004

ह

0.002

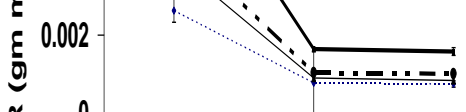

\begin{tabular}{lr|r|r|r}
$\frac{\pi}{4}$ & 0 & & & \\
\hline & & 1 & 2 & 3
\end{tabular} (c)

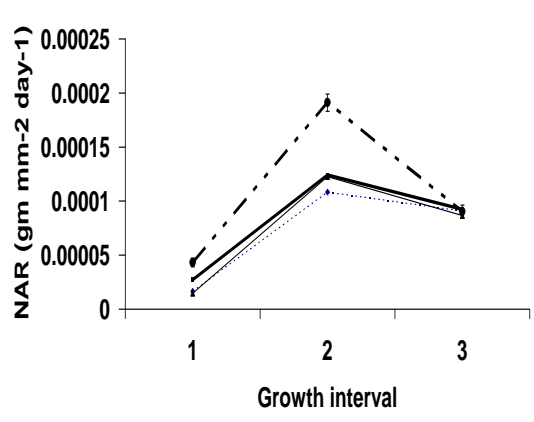

(b)

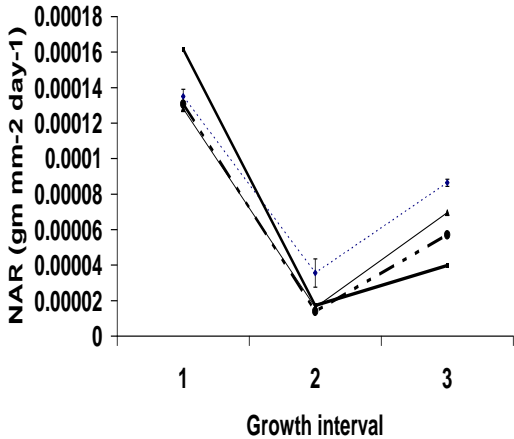

Fig. 7. Net assimilation rate (NAR) of C.procera $(a, c)$ and $F$. sativa $(b, d)$ subjected to the mulching treatment of $\boldsymbol{H}$. curassavicum (a,b) and $\boldsymbol{H}$. bacciferum $(\mathbf{c}, \mathrm{d})$ at different growth intervals; $1=$ seedling-juvenile, $2=$ =juvenile-mature and $3=$ matureflowering. Vertical bar around the mean is the standard deviation . 
C. procera
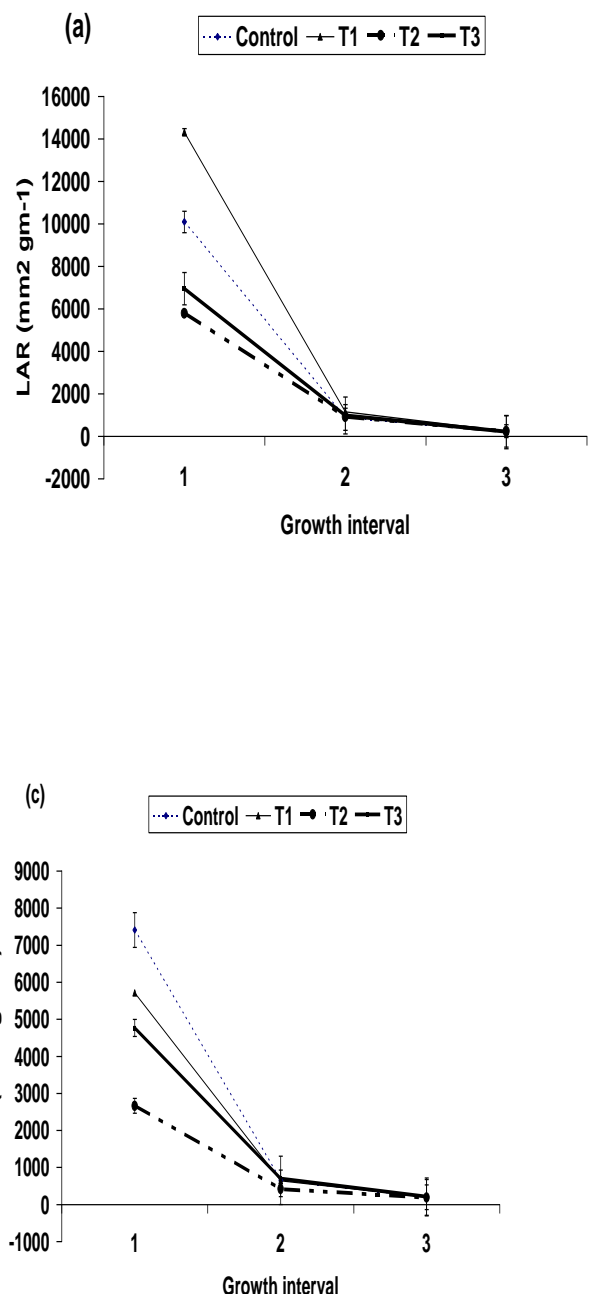

F. sativa
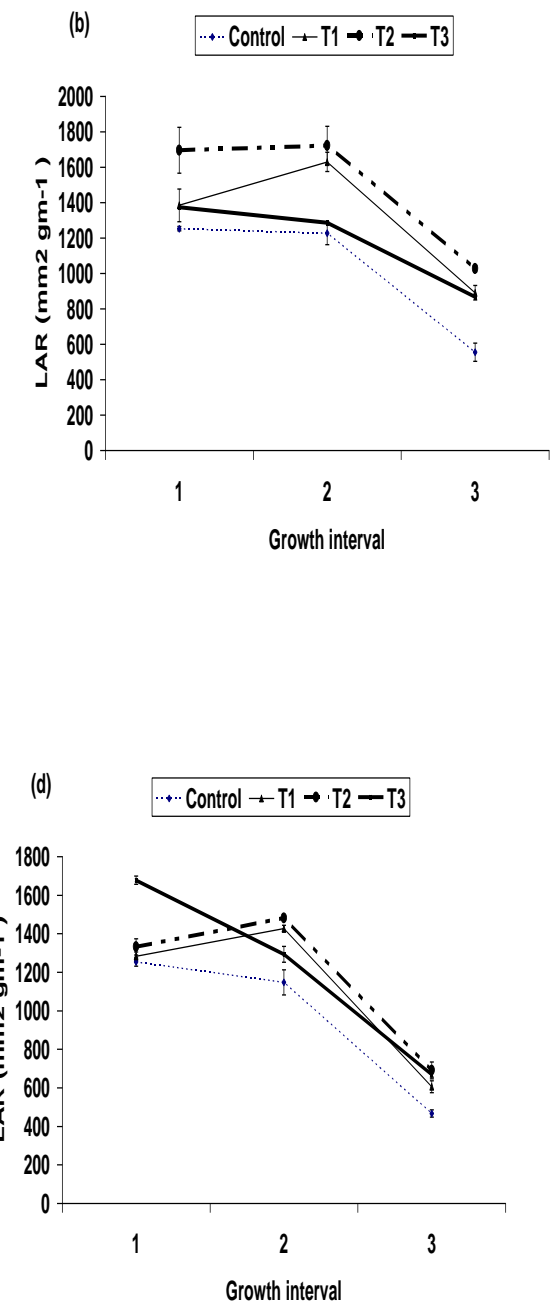

Fig. 8. Leaf area ratio (LAR) of $C$. procera $(\mathrm{a}, \mathrm{c})$ and $\boldsymbol{F}$. sativa $(\mathrm{b}, \mathrm{d})$ subjected to the mulching treatment of $\boldsymbol{H}$. curassavicum $(\mathrm{a}, \mathrm{b})$ and $\boldsymbol{H}$. bacciferum $(\mathbf{c}, \mathrm{d})$ at different growth intervals; $1=$ seedling-juvenile, $2=$ juvenile-mature and $3=$ mature-flowering. Vertical bar around the mean is the standard deviation. 
C. procera
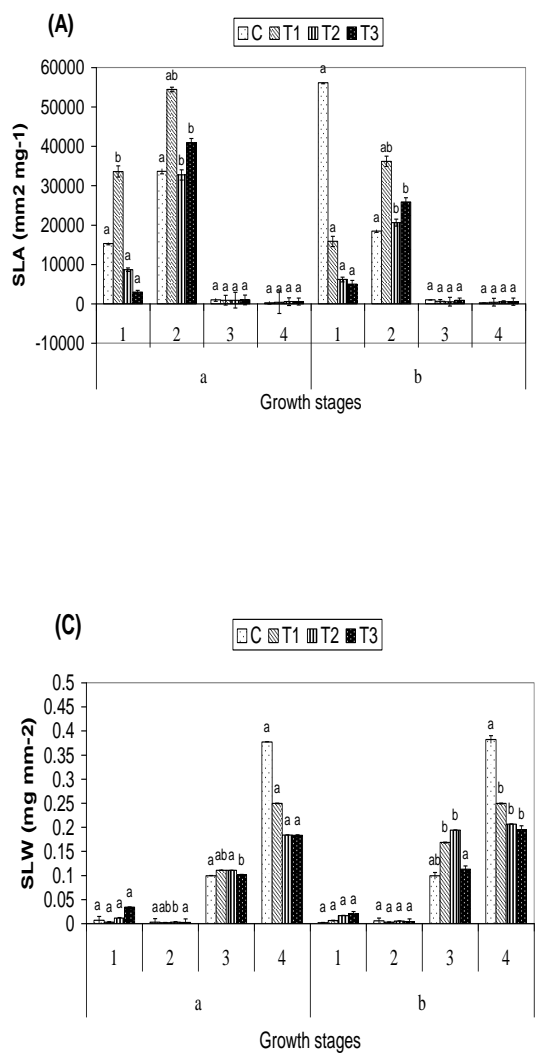

F. sativa
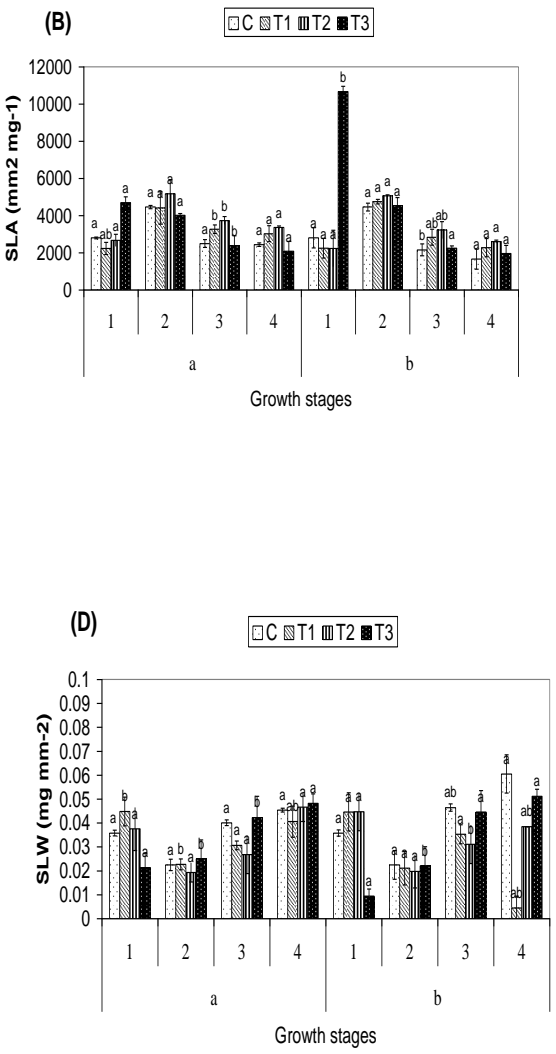

Fig. 9. Specific leaf area (SLA) and specific leaf weight (SLW) of $C$. procera $(A, C)$ and $F$. sativa $(\mathrm{B}, \mathrm{D})$ subjected to the mulching treatment of $\boldsymbol{H}$. curassavicum(a) and $H$. bacciferum (b) at different growth stages; $1=$ seedling, $2=$ juvenile, $3=$ mature and 4-flowering. Vertical bar around the mean is the standard deviation. 
TABLE 2. Correlations between the relative growth rate (RGR) and other growth parameters; net assimilation rate (NAR), leaf area ratio (LAR), specific leaf area (SLA) and specific leaf weight (SLW) of the test species as affected by mulching treatment of $(a)=H$. curassavicum and $(b)=H$. bacciferum, using Pearson correlation coefficient (Two-tailed test). $* \mathbf{P}<0.05, * * \mathbf{P}<0.01 . \mathbf{r}=$ correlation coefficient.

\begin{tabular}{|c|c|c|c|c|c|c|c|c|}
\hline \multirow{3}{*}{ Test species } & \multicolumn{4}{|c|}{ NAR } & \multicolumn{4}{|c|}{ LAR } \\
\hline & \multicolumn{2}{|c|}{ (a) } & \multicolumn{2}{|c|}{ (b) } & \multicolumn{2}{|c|}{ (a) } & \multicolumn{2}{|c|}{ (b) } \\
\hline & $\mathbf{r}$ & $\mathbf{P}$ & $\mathbf{r}$ & $\mathbf{P}$ & $\mathbf{r}$ & $\mathbf{P}$ & $\mathbf{r}$ & $\mathbf{P}$ \\
\hline \multicolumn{9}{|l|}{ C.procera } \\
\hline \multirow{4}{*}{$\begin{array}{l}\text { Control } \\
T_{1} \\
T_{2} \\
T_{3}\end{array}$} & $0.993 * *$ & 0.006 & \begin{tabular}{|l|}
0.350 \\
\end{tabular} & 0.560 & 0.775 & 0.235 & $0.975^{*}$ & 0.018 \\
\hline & 0.896 & 0.144 & \begin{tabular}{|l|}
0.448 \\
\end{tabular} & 0.632 & 0.546 & 0.264 & 0.981* & 0.019 \\
\hline & \begin{tabular}{|l}
0.457 \\
\end{tabular} & 0.674 & \begin{tabular}{|l|}
0.349 \\
\end{tabular} & 0.563 & 0.864 & 0.279 & 0.866 & 0.146 \\
\hline & \begin{tabular}{|l|}
0.465 \\
\end{tabular} & 0.451 & 0.279 & 0.731 & \begin{tabular}{|l|}
0.893 \\
\end{tabular} & 0.220 & 0.909 & 0.091 \\
\hline \multicolumn{9}{|l|}{ F. sativa } \\
\hline \multirow{4}{*}{$\begin{array}{l}\text { Control } \\
\mathrm{T}_{1} \\
\mathrm{~T}_{2} \\
\mathrm{~T}_{3}\end{array}$} & -0.993 & 0.077 & \begin{tabular}{|l|}
-0.549 \\
\end{tabular} & 0.825 & 0.836 & 0.370 & 0.917 & 0.347 \\
\hline & \begin{tabular}{|l}
-0.870 \\
\end{tabular} & 0.253 & -0.275 & 0.975 & $1.000 * *$ & 0.008 & 0.961* & 0.078 \\
\hline & -0.786 & 0.335 & 0.517 & 0.654 & $1.000 * *$ & 0.006 & 0.994 & 0.070 \\
\hline & -0.151 & 0.860 & 0.531 & 0.643 & 0.798 & 0.412 & $.953 *$ & 0.050 \\
\hline
\end{tabular}

\begin{tabular}{|c|c|c|c|c|c|c|c|c|}
\hline & \multicolumn{4}{|c|}{ SLA } & \multicolumn{4}{|c|}{ SLW } \\
\hline \multirow{5}{*}{\begin{tabular}{|l} 
C. procera \\
Control \\
$\mathrm{T}_{1}$ \\
$\mathrm{~T}_{2}$ \\
$\mathrm{~T}_{3}$
\end{tabular}} & & & & & & & & \\
\hline & $\begin{array}{l}0.639 \\
\end{array}$ & 0.361 & $0.993 * *$ & 0.007 & \begin{tabular}{|l|}
-0.929 \\
\end{tabular} & 0.071 & \begin{tabular}{|c|}
-0.914 \\
\end{tabular} & 0.086 \\
\hline & \begin{tabular}{|l|l|}
0.607 \\
\end{tabular} & 0.393 & 0.858 & \begin{tabular}{|l|l|}
0.142 \\
\end{tabular} & -0.809 & 0.191 & -0.915 & 0.085 \\
\hline & 0.998* & 0.062 & 0.636 & 0.364 & -0.718 & 0.282 & -0.837 & 0.163 \\
\hline & \begin{tabular}{|c|}
0.738 \\
\end{tabular} & 0.282 & \begin{tabular}{|l|}
0.851 \\
\end{tabular} & \begin{tabular}{|l|}
0.149 \\
\end{tabular} & -0.452 & 0.548 & \begin{tabular}{|c|c|}
$-0.961^{*}$ \\
\end{tabular} & 0.039 \\
\hline \multirow{5}{*}{\begin{tabular}{|l|} 
F. sativa \\
Control \\
$\mathrm{T}_{1}$ \\
$\mathrm{~T}_{2}$ \\
$\mathrm{~T}_{3}$
\end{tabular}} & & & & & & & & \\
\hline & 0.985* & 0.018 & 0.972 & 0.082 & -0.982 & 0.082 & \begin{tabular}{|l}
-0.947 \\
\end{tabular} & \begin{tabular}{|l}
0.209 \\
\end{tabular} \\
\hline & 0.954 & \begin{tabular}{|l|}
0.194 \\
\end{tabular} & 0.982 & \begin{tabular}{|l|}
0.079 \\
\end{tabular} & -0.956 & 0.187 & -0.974 & 0.134 \\
\hline & 0.971 & 0.155 & 0.987 & \begin{tabular}{|l|l|}
0.103 \\
\end{tabular} & -0.959 & 0.183 & \begin{tabular}{|c|}
-0.987 \\
\end{tabular} & 0.105 \\
\hline & $1.000^{* * *}$ & 0.006 & $0.997 *$ & \begin{tabular}{|l|}
0.046 \\
\end{tabular} & -0.853 & 0.051 & -0.994 & 0.069 \\
\hline
\end{tabular}

\subsection{Relative growth rate}

The RGRs of the two test species generally decreased as the plant age proceeded. Considering $C$. procera treated with $H$. curassavicum, the recorded RGRs for control, $\mathrm{T}_{1}, \mathrm{~T}_{2}$ and $\mathrm{T}_{3}$ plants were $0.09,0.1,0.09$ and $0.04\left(\mathrm{gm} \mathrm{gm}^{-1} \mathrm{day}^{-1}\right)$ during the seedling growth stage, while these values greatly reduced into $0.017,0.022$, 0.023 and $0.025\left(\mathrm{gm} \mathrm{gm}^{-1} \mathrm{day}^{-1}\right)$ at the flowering growth stage (Fig. 6,a). The same trend followed on treatment of $C$. procera by H. bacciferum (Fig. 6,c).

The RGRs for $F$. sativa plants treated by either H. curassavicum (Fig. 6,b) or $H$. bacciferum (Fig. 6,d) mulches showed similar trend $C$. procera but with one exception that the last two growth stages gave nearly equal values. In other words, RGRs in the early growth stage (seedling-juvenile) of $F$. sativa was affected by mulches than the late growth stages. 


\subsection{Net assimilation rate}

The effects of $H$. curassavicum and $H$. bacciferum on the NARs of $C$. procera and $F$. sativa was illustrated in Fig. 7.

The illustrated data revealed that the variations of NARs among the two test species were dependent on the test species and the growth stage. NAR of $C$. procera plants treated with $H$. curassavicum gave the lowest values at the seedling-juvenile growth interval for control and of the mulching treatments. The highest NAR values were recorded for the same treatments but at the matureflowering growth interval (Fig. 7,a). Similarly, the effect of $H$. bacciferum mulch on the NAR of $C$. procera showed the same trend with the exception of the second growth interval, which showed the highest value (Fig. 7,c).

Unlike to the obtained NAR results for $C$. procera, the recorded NAR values for $F$. sativa decreased as the plant ages. Maximum NAR values were recorded in the first growth interval (seedling-juvenile) then decreased at the following growth intervals (Fig. 7, b and d).

\subsection{Leaf area ratio}

The effect of $H$. curassavicum and $H$. bacciferum mulches on the LARs of the two test species was illustrated in Fig. 8. Both $C$. procera and $F$. sativa, attained the highest LAR values in the first growth interval (seedling-juvenile) and then these values decreased in the subsequent growth intervals recording the minimum values in the late growth interval (mature-flowering). $C$. procera plants treated with $H$. curassavicum recorded the maximum LAR values among the different test species as it recorded 10086.75, 14303.54, 5790.18 and $6943.79\left(\mathrm{~mm}^{2} \mathrm{gm}^{-1}\right)$ in control, $\mathrm{T}_{1}, \mathrm{~T}_{2}$ and $\mathrm{T}_{3}$ treated plants; respectively, during the seedling- juvenile growth (Fig. 8, a). Similar trend followed by $C$. procera treated with $H$. bacciferum and illustrated in Figure 8,c. LAR for F.sativa plants showed relatively smaller values in comparison to that of $C$. procera. Minimum LAR values were recorded for $F$. sativa plants treated by $H$. bacciferum in the third growth interval (mature-flowering) recording 554.2, 604.6, 690.5 and $669.2\left(\mathrm{~mm}^{2} \mathrm{gm}^{-1}\right)$ in control, $\mathrm{T}_{1}, \mathrm{~T}_{2}$ and $\mathrm{T}_{3}$ treated plants; respectively (Fig. 8,d).

\subsection{Specific leaf area}

There was general trend of decrease of the SLA values as the plant mulch treatment increase and as plants age (Fig.7). Plants of $C$. procera treated with $H$. curassavicum recorded SLA values amounted to 55287.95, 33589.76, 8644.06 and $2960.21 \mathrm{~mm}^{2} \mathrm{mg}^{-1}$ in control, $\mathrm{T}_{1}, \mathrm{~T}_{2}$ and $\mathrm{T}_{3}$ plants, respectively in the seedling growth stage. These values are reduced gradually in the subsequent growth stages recording minimum values amounted to 265.23, 401.04, 544.81 and $545.29 \mathrm{~mm}^{2} \mathrm{mg}^{-1}$, respectively, for the same treatments during the flowering growth stage of the same plant. In addition, the SLA values of control plants were relatively higher than that of treated plants using either one of the two mulch powders. For example, SLA in the mature growth stage of $C$. procera treated by $H$. bacciferum was $1010.52 \mathrm{~mm}^{2} \mathrm{mg}^{-1}$ and this value greatly reduced

Egypt. J. Bot., 54, No. 2 (2014) 
to about its half $\left(594.67 \mathrm{~mm}^{2} \mathrm{mg}^{-1}\right)$ using the first mulch treatment $\left(\mathrm{T}_{1}\right)$. The data revealed greater SLA values using either $C$. procera or $F$. sativa plants treated with $H$. bacciferum, than the test plant treatments by $H$. bacciferum. The recorded SLA values were 906.72 and $3731.01 \mathrm{~mm}^{2} \mathrm{mg}^{-1}$ for $C$. procera and $F$. sativa plants; respectively, and treated by $\left(\mathrm{T}_{2}\right) \mathrm{H}$. curassavicum during the mature growth interval. These values were greatly reduced into 515.71 and $3218.42 \mathrm{~mm}^{2} \mathrm{mg}^{-1}$ for the same plants and treatment but using H. bacciferum.

\subsection{Specific leaf weight}

Values of SLA and SLW for the two test species under the allelopathic potential of $H$. curassavicum and $H$. bacciferum was illustrated in Fig. 9. There was a reduction in SLA as the amount of mulch increased and as the test plants aged (Fig. 9, A and B). C. procera treated with $H$. curassavicum mulch showed the highest SLA values during the juvenile growth stage (Fig. 9, A). These values decreased gradually in the subsequent growth stages recording minimum values of 265, 401, 484 and $512\left(\mathrm{~mm}^{2} \mathrm{mg}^{-1}\right)$ for the same plant and treated with $H$. bacciferum during the flowering growth stage (Fig. 9, A). F. sativa showed smaller SLA values (Fig. 9, B) in comparison to those of $C$. procera. In addition, there was no clear trend on comparing the SLW values of control and treated plants using different mulch treatment among the different test species (Fig. 9, C and D).

Correlation between RGR and other growth variables was given in Table 2 . The data demonstrated that RGR was positively correlated with NAR, LAR and SLA, and was negatively correlated with SLW for all treatments of $C$. procera. $F$. sativa, showed negative correlation between RGR and NAR, SLW values and positive correlation with LAR and SLA. Considering $C$. procera treated with $H$. curassavicum, RGR values are highly and positively correlated with NAR values $(r=0.993, P<0.01)$ in control plants, compared to relatively weaker but positive correlations in the treated plants by $\mathrm{H}$. bacciferum (Table 2). The RGR values were positively and strongly correlated with NAR in both test plants using the mulches of the two Heliotropium species. Moreover, mulch treatments resulted in the high values of the correlation between RGR and SLA in the case of $F$. sativa and low correlations in $C$. procera.

\section{Vegetative attributes}

\section{Discussion}

Allellochemicals of $H$. curassavicum were identified as esters of the nonhepatotoxic saturated necine, trachelanthamidine (Subramaniam et al., 1980). In addition, allelochemicals of $H$. bacciferum were reported and isolated as an alkaloid related to acetyl indicine (Farrag et al., 2013).

Root length is found to be statistically more accurate than seed germination in assessing the response of test plants to allelochemicals (Cope, 1982). In accordance with inhibitory effects of the two Heliotropium mulches on the shoot height and root depth of the two test species of the present study, a reduction of 
plant growth as influenced by allelochemicals was reported by several investigators (Jabeen et al., 2011).

The current results which showed much inhibitory effects of the two Heliotropium species on both test species; $C$. procera and $F$. sativa, in the late growth stages, was explained by Farrag (2007). He reported that, the inhibitory effect of allelochemicals released by the plant mulch on shoot height and root depth of the other test species was observed in the late growth stages. Moreover, the accumulation of allelochemicals in the body of the test species may explain this behavior. In addition, soil microbes play an important role in the qualitative and quantitative availability of allelochemicals (Raoof and Siddiqui 2012). DeFrank and Putnam (1985) reported that soil-borne actinomycetes could enhance allelopathic effects. This may explain that the root depth of the test species of the present study was more affected by the inhibitory effect of allellochemicals than that of shoot length.

The values of root-shoot (R:S) ratios for C.procera and F.sativa treated plants with either H.curassavicum or H.bacciferum mulches, were less than those of untreated plants (controls), this was explained by Nilsson (1994) who suggested that the decrease in root/shoot ratio as a response to nutrient deficiency appears to be applied for plants subjected to allelopathic interactions.

\section{Reproductive attributes and dry matter allocation}

Less number of flowers per individual was recorded in the treated plants as compared with control plants of the present study. In this regard, many authors (Bich and Noguchi 2012) have reported the inhibitory effects of allelochemicals on the chlorophyll content and net photosynthetic rate of their test species which intern affect the reproductive opportunity of the test species. This feature is considered as a plastic response of the allelopathically stressed plants which enables them to live but with a diminished reproductive growth (Raynal and Bazzaz 1975).

\section{Growth analysis}

The relative growth rate of plants is determined by their genetic background and by environmental conditions (Rafael et al. 2005). The RGRs of most test species of the present work generally decreased with plant's age. This is in agreement with slow RGR that was observed by Hegazy and Ismail (1992) as a result of decreased age-specific LAR and slow NAR that reflect the decreased amount of leaf production with age resulting in slower growth. On the other hand, RGRs of controls of the present work are generally higher than that of treated plants especially in the case of $C$. procera. The slow RGR of treated plants may be implied by the toxic allelochemicals released from the mulch of the two Heliotropium species. In addition, the higher RGR of controls as compared to treated plants may be explained by the increment of dry matter allocated to the leaves. This means that better RGR in controls and mild treated plants $\left(\mathrm{T}_{2}\right)$ as compared to high mulch treated plants $\left(\mathrm{T}_{3}\right)$. Similarly, Sayed and Hegazy (1994), found that the pattern of RGR increment followed that of dry matter allocated into vegetative parts (stem and leaves) and a decrease in RGR

Egypt. J. Bot., 54, No. 2 (2014) 
resulted from an increased dry matter allocated to sexual structures (flowers and fruits) at the expense of vegetative parts. In addition, the reduced dry mass and RGR of rice with increased density of lotus rhizomes indicates a possible response to allelopathic interference (Hegazy et al., 2001). The observed increase in RGR during the seedling-juvenile growth interval which was followed by a decrease in the later growth intervals was observed in $F$. sativa. This may be explained by the fact that the growth rate in the seedling- juvenile growth interval is normally the most rapid in the life of desert plants in comparison to the subsequent growth intervals (Burdon and Harper 1980).

The wide variation in RGR among species was explained mainly by the variation in the plant morphological variables, such as LAR and in particular the SLA. This finding is in agreement with many other studies supporting SLA as a major factor associated with variation in the RGR (Chengxu et al., 2011).

In accordance with findings of Farrag (2007), the variation of NAR between the two test species and among the control and treated plants of the same test species was very dynamic with age. Variability of NAR values among different species was parallel to the fluctuations in the RGR values. The test species attained the highest LAR values in the first growth interval, emergence-seedling, and then the values decreased in the subsequent growth intervals. This trend could be attributed to the decrease of the SLA values as the plants age. The positive correlation between RGR and other growth variables is in agreement with findings of many authors (Rafael et al., 2005). In addition, environmental conditions determine both the realized RGR and the relative importance of the other growth components. Studies have challenged the general view of SLA as a major determinant of RGR. Shipley (2002) argued that the commonly reported result that "the interspecific variation in RGR is determined primarily by SLA", is partly due to low irradiance used in most experiments. Therefore, the relative importance of SLA and NAR would change depending on the irradiance perceived by plant. In another study, Loveys et al., (2002) found that RGR was significantly and positively correlated with NAR, when plants were cultivated at $18{ }^{\circ} \mathrm{C}$. However, when growth temperature increased to 23 or $28{ }^{\circ} \mathrm{C}$ the RGR pattern switched, and correlated positively with SLA, which is in agreement of results of the present work.

\section{Conclusion}

In conclusion, the present study revealed that mulch treatments with the invasive plants $H$. curassavicum and/or $H$. bacciferum greatly suppressed the vegetative growth and dry matter allocation of the two test species. Moreover, the allelopathic effect of both $H$. curassavicum and $H$. bacciferum concerning number of flowers showed more inhibitory effect towards $F$. sativa than C. procera. Root/shoot ratio of control plants were generally reduced under the mulch effect and this reduction reaches its maximum in the late growth stages. The RGRs of most test species generally decreased with age as a result of decreased age-specific LAR and slow NAR. Variability of NAR values among different species may be explained by the fluctuations in the RGR values of this 
species. Correlation between RGR and other growth variables demonstrated that RGR positively correlated with NAR, LAR and SLA for all treatments of $C$. procera, while the test species $F$. sativa, showed negative correlation between RGR and NAR values and positive correlation with LAR and SLA. The present study recommend the use of the two Heliotropium species for the biocontrol of harmful shrubs like $C$. procera and at the same time alert for the inhibitory effect of these species on the growth of economic plants like $F$. sativa.

\section{References}

Bich, T.T.N. and Noguchi, H.K. (2012) Allelopathic potential of two aquatic plants, duckweed (Lemna minor L.) and water lettuce (Pistia stratiotes L.), on terrestrial plant species. Aquat. Bot., 103, 30-36.

Burdon, J. J. and Harper, J. L. (1980) Relative growth rates of individual members of a plant population. J. Ecol., 68, 953-957.

Chengxu, W., Mingxing, Z., Xuhui, C. and Bo, Q. (2011) Review on allelopathy of exotic invasive plants. Proc. Eng., 18, 240-246.

Cope, W. A. (1982) Inhibition of germination and seedling growth of eight forage species by leachates from seeds. Crop Sc., 22, 1109-1111.

DeFrank, J. and Putnam, A. R. (1985) Screening procedure to identify soil-borne actinomycetes that can produce herbicidal compounds. Weed Sc., 33, 271-274.

Djurdjević, L., Gajić, G., Kostić, O., Jarić, S., Pavlović, M. and Mitrović, M. (2012) Seasonal dynamics of allelopathically significant phenolic compounds in globally successful invader Conyza canadensis L. plants and associated sandy soil. Flora, 207, 812-820.

Farrag, H.F. (2007) Allelopathic Potential of some Invasive Weeds in Egypt. Ph.D. Thesis, Botany Department, Faculty University, Cairo University.

Farrag, H.F. (2012) Floristic composition and vegetation-soil relationships in Wadi AlArgy of Taif region, Saudi Arabia. Int. res. J. Pl. Sc., 3(8), 147-157.

Farrag, H.F., Sliai, A.M. and Mhmas, T.F. (2013) Allelopathic potentiality of two Heliotropium species on germination and protein expression of some plants, Int. Res. J. Biotech., 4(3), 47-60.

Florentine, S.K. and Westbrooke, M.E. (2005) Invasion of the noxious weed Nicotiana glauca R. Graham after an episodic flooding event in the arid zone of Australia. $J$. Arid Env., 60 (4), 531-545.

Hegazy, A. K. and Ismail, S. M. (1992) Autecology of desert monocarpic Rumex cyprius as influenced by water treatment. Acta Oecol., 13, 193-202.

Hegazy, A. K. (1994) Trade-off between sexual and vegetative reproduction of the weedy Heliotropium curassavicum L. J. Arid Env., 127, 209-220. 
Hegazy, A. K., Amer, W. M. and Kheder, A. A. (2001) Allelopathic effect of Nymphaea lotus L., on growth and yield of cultivated rice around Lake Manzala (Nile Delta). Hydrobiolgia, 464, 133-142.

Hunt, R. (1978) "Plant Growth Analysis. Studies in Biology". No. 96. The Camelot Press Ltd., Southampton, Brittain, 67 pp.

Inderjit, Seastedt, T.R., Callaway, R.M., Pollock, J.I. and Kaur, J. (2008) Allelopathy and plant invasions: traditional, congeneric, and biogeographical approaches. Biol. Invas., 10, 875-890.

Jabeen, N., Ahmed, M. and Shaukat, S.S. (2011) Interactive activity of Asphodelus tenuifolius on germination and growth of wheat (Triticum aestivium L.) and sorghum (Sorghum bicolor L.) Pak. J. Bot., 43 (1), 325-331.

Kim, Y.O. and Lee, E.J. (2011) Comparison of phenolic compounds and the effects of invasive and native species in East Asia: support for the novel weapons hypothesis. Ecol. Res., 26, 87-94.

Loveys, B. R., Scheurwater, I., Pons, T. L., Fitter, A. H. and Atkin, O. K. (2002) Growth temperature influences the underlying components of relative growth rate: An investigation using inherently fast- and slow- growing plant species. Pl. Cell Env., 25, 975-997.

Mansour, M.M.F. (2013) Plasma membrane permeability as an indicator of salt tolerance in plants. Review, Biol. Plant., 57(1), 1-10.

Nilsson, M.C. (1994) Separation of allelopathy and resource competition by the boreal dwarf shrub Empetrum hermaphroditum Hagerup. Oecologia, 98, 1-7.

Rafael, V., Teodoro, M., José, L.Q., Pilar, P., Francisco, A. and Hans, L. (2005) Variation in relative growth rate of 20 Aegilops species (Poaceae) in the field: The importance of net assimilation rate or specific leaf area depends on the time scale. in Pl. Soil, Springer, 272, 11-27.

Raoof, K.M.A. and Siddiqui, M.B. (2012) Allelopathic effect of aqueous extracts of different parts of Tinospora cordifolia (Willd.) Micrs on some weed plants. J. Agric. Ext. Rural Dev., 4(6), 115-119.

Raynal, D. J. and Bazzaz, F. A. (1975) Interference of winter annuals with Ambrosia artemisifolia in early successional fields. J. Ecol., 56, 37-49.

Rice, E. L. (1984) Allelopathy. Academic Press, Orlando.

SAS (1985) SAS/STAT guide for personal computers, version 6 edition. SAS Institute, Cary, NC.

Sayed, O.H. and Hegazy, A.K. (1994) Growth-specific phytomass allocation in Mesmbryanthemum nodiflorum as influenced by CAM induction in the field. J. Arid Environ., 27, 325-329. 
Shipley, B. (2002) Trade-offs between net assimilation rate and specific leaf area in determining relative growth rate: Relationship with daily irradiance. Func. Ecol., 16, 682-689.

Subramaniam, P.S., Mohanraj, S., Cockrum, P. A., Culvenor, C. C. J., Edgar, J. A., Frahn, J. L. and Smith, L. W. (1980) Aust. J. Chem., 33, 1357.

Thorpe, A.S., Thelen, G.C., Diaconu, A. and Callaway, R.M., (2009) Root exudate is allelopathic in invaded community but not in native community: field evidence for the novel weapons hypothesis. J.Ecol., 97, 641-645.

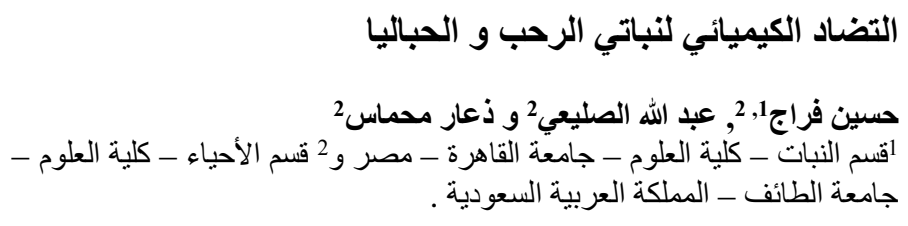

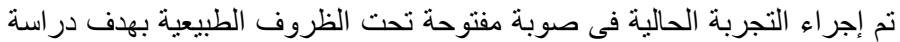

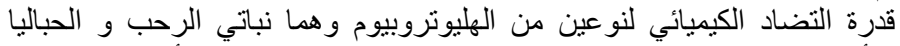

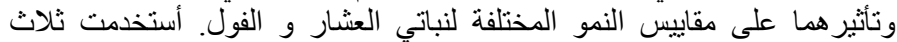

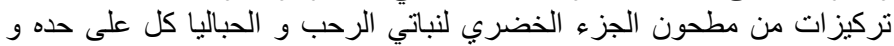

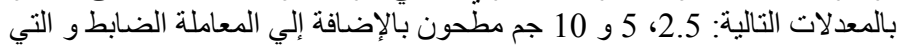

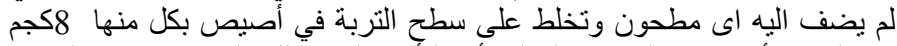

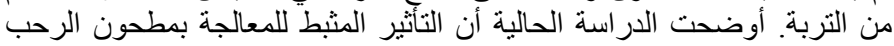

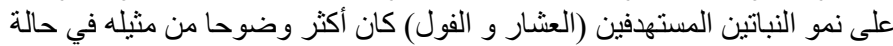

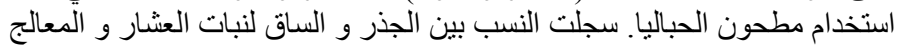

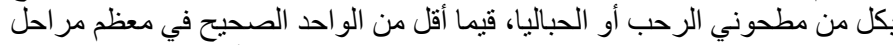

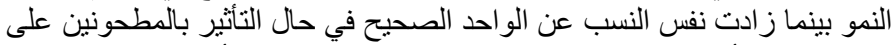

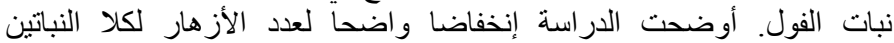

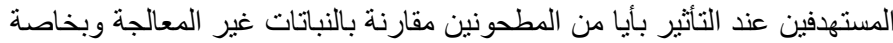

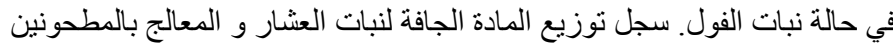

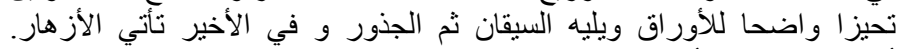

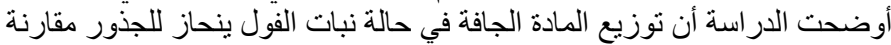

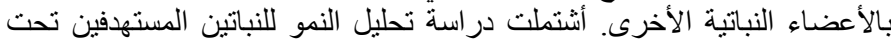

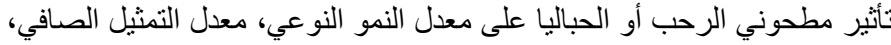

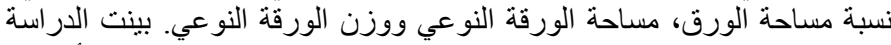



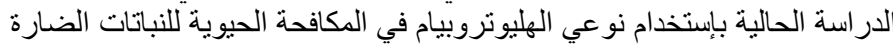

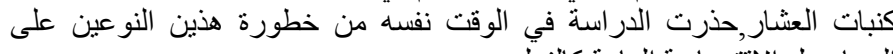
المحاصيل الإقتصادية الهامة كالفولّ الرئ.

Egypt. J. Bot., 54, No. 2 (2014) 
(d)

(d)

$\triangle I$

(d)

$\longrightarrow$ I I

10

Egypt. J. Bot., 54, No. 2 (2014) 